\title{
Marginalized Primary Education on Ethnic Bajo in Saponda Village, Konawe Regency: Limited Access to Education \& Educators
}

\author{
I Ketut Suardika ${ }^{1, *}$, Lisnawati Rusmin ${ }^{1}$, Rohmana $^{2}$, La Anse ${ }^{1}$, Erny Harijaty $^{3}$, Fina Amalia Masri ${ }^{4}$ \\ ${ }^{1}$ Elementary School Teacher Study Program, Universitas Halu Oleo, Indonesia \\ ${ }^{2}$ Department of English Language Education, Universitas Halu Oleo, Indonesia \\ ${ }^{3}$ Department of Indonesian Language Education, Universitas Halu Oleo, Indonesia \\ ${ }^{4}$ Department of Language and Literature, Universitas Halu Oleo, Indonesia
}

Received March 7, 2020; Revised April 7, 2020; Accepted May 13, 2020

Copyright@2020 by authors, all rights reserved. Authors agree that this article remains permanently open access under the terms of the Creative Commons Attribution License 4.0 International License

\begin{abstract}
Use of Getting access to useful and proper education is the right of every citizen guaranteed in the constitution. In fact, to this day, the Bajo ethnic community is still marginalized, especially with access to education. The purpose of this study is to determine several things that are the focus of the forms of exclusion and limitations of primary education in the Bajo ethnic community in Saponda Village, Soropia District. The method used in this study is a qualitative research method using descriptive analysis approach. Data collection was carried out through observation, in-depth interviews, and Focus Group Discussion (FGD). The research location was centred in the village of Saponda, located in a small island called Soropia District, Konawe Regency, Southeast Sulawesi, Indonesia. The study's findings indicate that this form of marginalization of primary education that is found among others the feasibility of inadequate education, educational facilities, teaching staff, the educational process is less so that the ratio of teachers and students were not feasible.
\end{abstract}

Keywords Primary Education, Bajo Ethnic, Limitations, Education

\section{Introduction}

The process of education in the global era seems to bring very rapid changes to the development of science and technology; consequently, it can have an impact on human life patterns [1]. These impacts can cause a shift in the design of life and human behaviour, which is characterized by various symptoms, such as (1) the formation of local communities into the world community, (2) the emergence of social cohesion into democratic participation, and (3) the economic acceleration towards qualified human resources. In this context, Tilaar [2] mentions with the global challenges the education world builds competitive and innovative societies. According to him, in open life, a world without limits. Therefore, the universal experience is not only a challenge but also opens new opportunities to improve the standard of living of the Indonesian people and the nation. Thus, the orientation of the national education system must not be separated from its duties and responsibilities to provide opportunities and better access to education at all levels of society.

Even after the government launched the tri education centre as a system, namely family education, environmental education and school education [3], however, what counts in both the world of work and social status is a graduate of formal education. This condition will not be a problem if the government can guarantee the involvement of all citizens informal education. Legal education, when viewed from its level, then primary education (Elementary school and Junior High School) is an educational institution that aims to lay the foundations of education for every child in this country [4]. Thus there is no reason for anyone to take the path of primary school. Every citizen is obliged to undergo a 9-year primary education. Therefore, the government must be able to guarantee both the policy and implementation aspects, starting at the central level to the regional government. So that in the future, there will be no more citizens who have not received a 9-year primary education [5].

However, the reality is that the condition of the community, which is mostly in poverty and underdeveloped social facilities, is still in the circle of weak education and human resources[6]. Some 
observations obtained indicate that the risk of child workload from fishing families is much more substantial. It is because due to the tendency of poor rural communities children are generally expected to take part in the economic activities of their family heads, and this condition causes the child's time reserved for educational activities. The living conditions of fishing communities who generally live below the poverty line. Some of these causes are due to isolated geographic location, fatalistic culture, patriarchal culture, and closed attitudes. They are thus making change agents less interested in approaching through empowerment/education, One community that deserves to be a joint study that is part of the Bajo tribal fishing community group that inhabits many coastal areas, especially Southeast Sulawesi.

Statistics on the potential of coastal villages in 2000 showed that of the total population of Southeast Sulawesi of 1.666 .731 , as many as 107.536 residents of coastal communities as farm households (meant fishermen) and 79.022 prehistoric families. Of the 1.555 villages in Southeast Sulawesi, there are 632 coastal villages (40,7\%) and 132 villages where most of the population work in the fishing sector [7]. One of the fishermen is a fishing community in Konawe Regency who generally live in poor villages and are more dominant in small islands, including the Saponda island. They consist of several ethnic groups including Bajo, Bugis, Muna and various Buton tribes.

Bajo tribe is the majority of traditional fishermen in this area[8]. It has quite severe liver problems, especially in the socio-cultural field, such as poverty and backwardness problems caused by low levels of knowledge and skills and ownership of relatively small production factors. Bajo tribe is a sea-cultured ethnic group. Data from 1991 confirms that there are 350,000 if the Bajo tribe scattered in Southeast Sulawesi, who are generally (99\%) as fishermen and are living below the poverty[9]. This condition influenced by the pattern of their settlements on the coast/waters [10]. Bajo tribal settlements that used to live in groups based on their ethnicity and the frequency of their mobility from one place to another are relatively high. Causing not easily touched by the national education system, so they maintain the original student system (indigenous learning system).

However, in Konawe District, most of their settlements occupy the coast (on land), but their living conditions are still in poverty. They have not realized the meaning of education in their lives and have not yet placed education as a necessity. So they have not felt much the benefits of education for improving skills according to their needs. In reality, this happens because the education system offered to them so far is not by their socio-cultural and natural environment as fishing communities [11], [12]. Bajo tribal fishing communities, especially those who live in the village of Saponda (Saponda Island) generally live as beach fishermen or traditional fishers [13]. Their settlement is on a small island with an area of $\pm 4 \mathrm{~km} 2$ or $400 \mathrm{Ha}(200 \mathrm{~m} \times 200 \mathrm{~m}$ ) whose natural environment is not supportive because clean sanitation is easily polluted by corpses that buried in the middle of residential areas. Every year there is an abrasion so that poverty makes life challenging to urge on a narrow island). To date, there have been no preventive measures either in the form of reconstruction of settlement systems and carrying capacity of coastal areas, development of coastal defences from abrasion.

Preliminary observations show that the development of the education sector is an equitable pillar of educational access services quantitatively that there has been a service gap and limited access to primary and secondary education between urban and rural areas. Gaps in the aspects of expanding and equitable access to education that there are differences related to the development process in the education sector [14]. The gap in the elements of expansion and equal access is known based on the average achievement of school dropouts for educators aged 13-15 years in urban areas reaching $89.3 \%$ per cent while for residents in rural areas only reaching 65.6\% (Konawe Education Development Report, 2009).

Conditions of access to education services in remote rural areas experience many limitations [15]. It caused by various factors including the specific geographical conditions of the region, accessibility of education, spatial accessibility and regional infrastructure. The main factors that can cause disparities between areas include geography, history, politics, government policy, administration, social culture and economics [16]. Responding to that, since 2006, the Konawe District government has set the priority development plan of the education sector development contained in the Medium-Term Development Plan. Specifically, the priority achievement of the 9-year compulsory education completion program at the elementary school level in the aspect of equity. The main target to be achieved is to expand and evenly distribute education services aged 7-12 years, especially in rural areas, namely Saponda Village, which is very isolated and lives in the islands, as well as for children with special needs by not differentiating sex through the provision of teaching staff or elementary school teachers of civil servants.

However, the implementation of the distribution of efforts in remote rural areas is not optimal can be implemented due to various obstacles faced including different geographical conditions, spatial accessibility conditions and limited regional infrastructure (https://www.depdiknas.com-dirjen). In line with the era of regional autonomy, the management of primary and secondary education becomes the authority and responsibility of local governments, where the role of local government institutions emphasized in providing optimal service and support for school principals so that the educational process runs effectively and efficiently [17]. Thus the part of the government shifted from the regulator to the facilitator, especially the 9-year compulsory education program, which is a target determined by the 
government to achieve equitable distribution and expand access to primary education.

The existence of schools on Saponda Island is still a significant complaint [18]. This complaint arises because in terms of facilities and infrastructure and educators very less compared to other schools in Soropia district Konawe district. Specifically, in the initial observations, Saponda village is $90 \%$ rice line inhabited by Bajo tribes, still separating the complexity of issues that are so complex ranging from education, economic, social or cultural issues. For the current education problems, for example, the lack of educators, the need for inadequate educational facilities, the learning process that is not effective and stable, education is only used as a tool of the hegemony of power that occurs is a process of ongoing marginalization. In the socio-economic field, until now, the community is only dependent on marine resources; as a result, the problem of poverty is still quite significant on this island. The environmental issue in this region is that each year continues to experience substantial coastal abrasion. Then the socio-cultural issues that are still patriarchal and the awareness of education to send their children to school are lacking.

Based on the description, the island has a unique and complex problem with the target point of the Bajo ethnic community. In addition to being enjoyable to explore further, it also deserves to be raised to the surface as a social responsibility, so it expected to receive even greater attention from Regency, provincial, central government and community governments.

\subsection{Research Questions}

The deep questions in this study are: What is the form of marginalization and limitations in primary education of the Bajo fishing community in Saponda Village, Soropia District, Konawe Regency?

\subsection{The Purpose of Research}

The objectives of this research study are to find out the forms of marginalization and limitations of primary education in the Bajo fishing community in Saponda Village, Soropia District, Konawe Regency

\section{Methods}

\subsection{Research design}

Research on the marginalization and limitations of primary education in the Bajo tribe community in Saponda Village, Soropia District, South Konawe Regency, Southeast Sulawesi Province is a cultural education study which is part of the research using qualitative methods. Efforts to obtain information by research questions and research objectives. The technique used in research is qualitative [19]

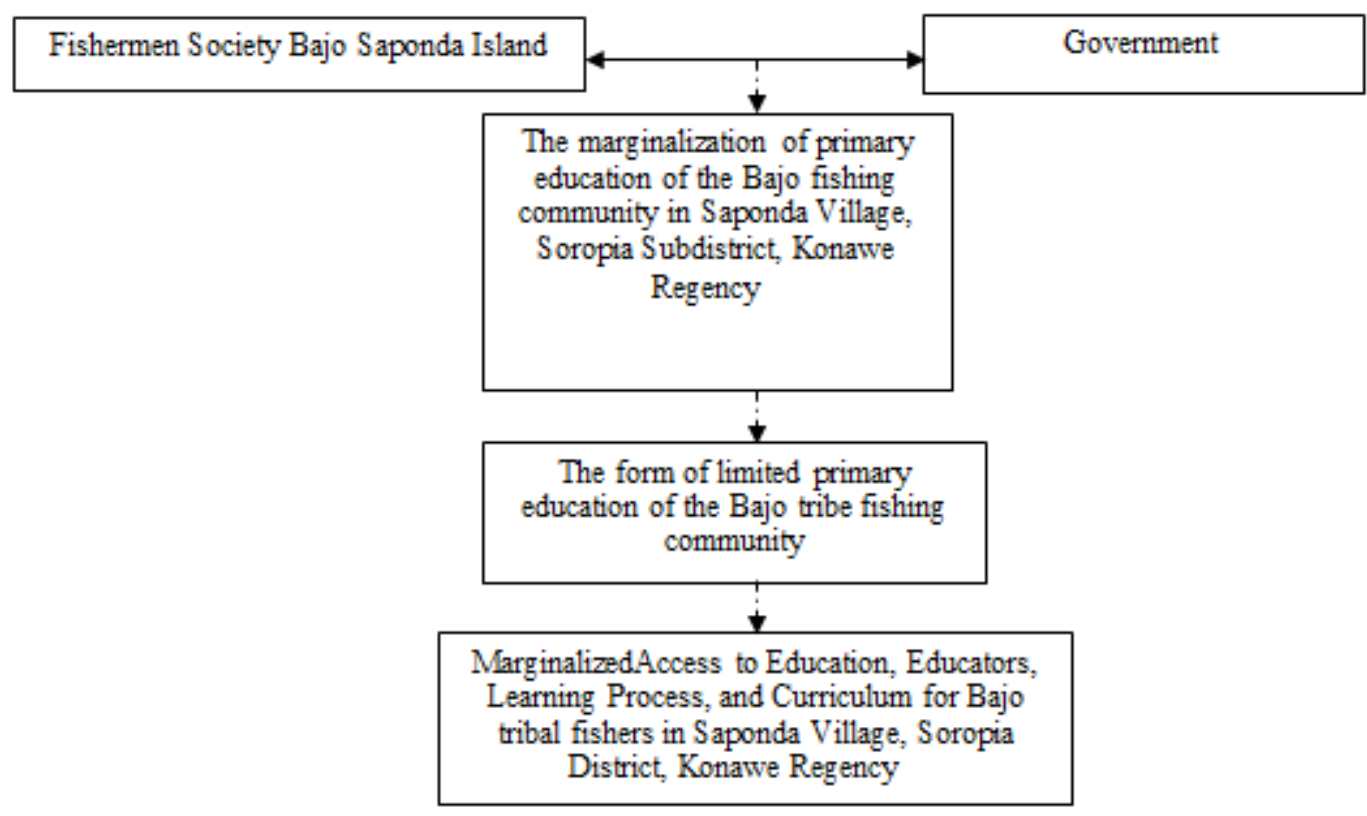

Figure 1. Research design 


\subsection{Research Location}

The study was conducted in Saponda Village, Soropia District, Konawe Regency, Southeast Sulawesi Province. In addition to the location of the setting study, the focus of his work was on the basic marginalization of the Bajo tribe in Saponda Village, Konawe Regency. Education is now a complicated issue for socio-cultural development in this case the marginalization in Saponda Village is a remote area surrounded by the sea and occupied by the Bajo tribe fishing community who settled around the 1930s.

The selection of Saponda Village / Saponda Island as the location of this study is based on several considerations, namely; (1) The complexity of the social problems of the community in Saponda Village shows several exciting phenomena to be examined and explored, especially the issue of access to education, including policies and their implementation; (2) The research location is a small island which is inhabited by most Bajo people who depend on their lives at sea while obtaining injustice in development so that economic conditions are still limited; (3) The location took in 3.5 hours if the seawater conditions are shady, but if the requirements of the big waves can be taken 4.5 hours from the city of Kendari using an outboard boat. It is at least the three factors that most underlie researchers feel interested in raising and conducting further studies and research to explore and exclude this community into a healthy and empowered community both culturally, educationally and economically.

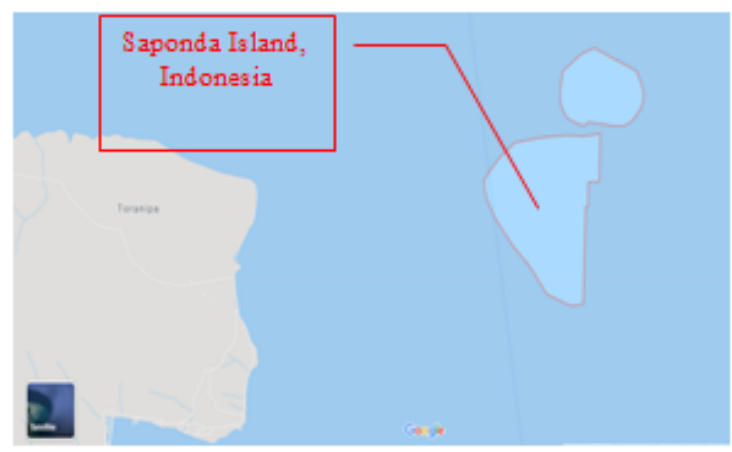

Figure 2. Location of Saponda Village, Soropia District

\subsection{Data Types and Data Sources}

The type of data collected in this study is qualitative data that is supported by quantitative data as gender data qualitative data in the form of descriptions, narratives, words and expressions that relate to the marginalization of primary education of the Bajo fishing community in Saponda Village, Soropia District, Konawe Regency.

This study uses two data sources, namely primary data sources and secondary data sources. Primary data were obtained directly by researchers through in-depth interviews from several informants, such as the Head of the Provincial, District, District Education Office, School Principal, Saponda State Elementary School Teacher, murmured parents, community leaders, committee officials, village heads of Saponda, and several former students who have dropped out of school. While secondary data sources are data obtained from the village profile documents of the Saponda village, Soropia sub-district, school data (Primary data, Junior High School and Senior High School), and reports from the Local Education Office, this research not intended to obtain generalizations, but rather to explain phenomena that are studied in-depth and meaningfully.

\subsection{Determination of Informants}

Determination informants referred to in this study is not a limitation on the number of informants but a consideration of researchers in deciding who is appropriate and by the needs of information gathering. In research, the data first obtained through crucial informants who can then be developed to other informants purposively. In this study, the researcher determined the informant purposively with consideration, namely: (1) having personal experience by the problem under study, (2) physically Mentally healthy, (3) concerned neutral and having no own interests, (4) community leaders, and (5) the person has broad knowledge according to the problem under study.

There were 27 informants. The number of 27 people was meant by focus group discussion participants, especially elementary and junior high school teachers from Saponda who were directly involved in the group discussion process in this research process. Also, the determination of informants in this research was carried out when the researcher entered the field and during the study (new sampling design), that is by asking for consideration and proposals from crucial informants when conducting interviews. It is prepared by researchers solely to get as much information as possible, and researchers stop the search for information when the data obtained has been deemed accurate, valid and reliable.

\subsection{Research Instrument}

The main instrument in this study is the researcher himself, using interview guides equipped with tape recorders, cameras/camcorders and anecdotal notes. Interview guidelines with open-ended questions can be directed to be more specific that the informant answers verbally. The interviews conducted by the author are face to face. To maintain the validity of the data four audit criteria used, which include credibility, transferability, dependability and confirmability [19]. The validity of the data is triangulated, as is commonly used in qualitative research. Triangulation of data sources is finally by finding data from informant sources, namely people directly involved with the object of study.

\subsection{Data Collection Technique}

The data collection process carried out interactively and 
non-interactively. Data collection based on interactive techniques carried out in the form of interviews and non-interactive such as observation and document study.

\subsection{Data Analysis Technique}

Data collected in this study analyzed with qualitative and interpretive descriptive. The descriptive analysis used to simplify all data collected, present it systematically, then manage, interpret the data collected. In this study, applying data exclusion criteria so that this process is commonly called sampling, i.e. discarding less relevant data and entering relevant data to answer research problems which are then used to obtain convincing power and support the concept or the building of a theoretical statement.

\subsection{Data Analysis Results Presentation Techniques}

Research results of the analysis are presenting data by organizing and compiling in relationship patterns so that researchers easily understand the data. In this research, the data presentation done informally and formally. Informal presentation techniques are descriptive or narrative, while formal presentation techniques are displayed through charts, tables and figures.

\section{Result and Discussion}

\subsection{Limited Access to Education}

Conceptually, there are no rules for local governments to treat unfairly for people who may be geographically remote because of transportation access, especially in small island areas such as the Saponda island/village. It is not the case, and this paper addresses the problem of marginalization of primary education in the Bajo tribe community in the town of Saponda. One factor that is the focus of attention in looking at this marginalization is access to public education, mainly formal education in elementary and junior high school education levels.

Access to education meant in this section is the ease and ability of the community to obtain basic educational needs for their children. Thus the reviews in this chapter are more general about the availability of educational institutions and population facilities to get formal education at various levels, from elementary to junior high. Although the substantive subject of this discussion will describe the findings of the form of marginalization of learning from the community at the study site, as an entry point, it will be described in general about the ways of accessing public school to various levels of education.

The phenomenon of the village of Saponda can be understood as an absorbed village because the condition is a small island in the middle of the high seas. Still, it has a relatively dense population, as described in the previous chapter. Due to regional conditions, the village is physically isolated. The term of the remote town does not mean that its occupation must lose its fundamental rights as citizens, that is, obtain an education. This assumption is very reasonable to guaranteed by the constitution also every year; the village always pays taxes.

One form of discrimination that is felt by the community is limited access to education. In this village, there were only elementary schools that were built in 1971 and then procurement (SATAP Indonesia named) in 2006. The procurement of SATAP junior high school to accommodate primary school output in this village, in fact since SATAP junior high school exists. The interest of children in this village has begun to continue their schooling at SATAP (Indonesia named) Saponda junior high school. This condition is considered as a form of discrimination, as described by La Milu (28 February 2011) one of the SATAP junior high school (Indonesia named) teachers. The limitations of education and existing facilities are forms of discrimination that exist is a form of discrimination that impacts the minimal number of students who continue their education at a higher level. As a direct quote below:

"We feel that there has been a form of discrimination, especially related to the facilities and procurement of SATAP (Indonesia named), which until now has limited teachers. It makes the interest of elementary school students less eager to continue to a higher level. From the data we know that the output of elementary school Saponda who continued their education at SATAP junior high school (Indonesia named) is approximately 50-60 per cent, some continued at junior high school on the mainland. Some did not stay"(Interview).

This expression and what is experienced by students in this school conflict with the 2008 Konawe Regency RPJMD (Indonesia named) and the 2010 education department strategic plan that desires, namely (1) Giving the maximum opportunity for all school children to continue their education, (2) Rehabilitation of damaged classrooms and provision of facilities, (3) Construction of new school units and RKB (Indonesia named). What has happened to the planning and policy of the local government has not touched the area of Saponda village.

Thus, community access to education in this village is remarkably prioritizing, conditions cannot wholly blame the community, or the children here do not want to continue their schooling. Many factors must be seen why they do not have the interest to continue their education. Many factors must be understood why they do not have the interest to continue their schooling. In addition to the limited conditions of school services, also can not be separated from government support that has been impressed not to pay attention or to put aside efforts to improve community education. Both in the form of improving facilities and infrastructure supporting education, as well as efforts to improve the quality capacity educators. 
The most recommended form of marginalization in this place is the poor placement of teachers, so the teacher and student ratio is not balanced. This condition strengthened by the observations made during the study site, almost during school hours, i.e. around 09.00-11.00 many students who roam and play without attention from their teacher. The lack of service and educational facilities, the lack of willingness of children in this village to continue their education is also inseparable from the weak encouragement of their parents. It said by $\mathrm{H}$. Lukman (Keponda Elementary School Saponda). The direct quotation can be described as follows:

"Weak access to education, in addition to government factors, also from the community itself. There is an impression that parents feel less motivating their children to go to school. The availability of elementary schools and junior high schools SATAP (Indonesia named) suggests that there are educational facilities than expected to accommodate 9-year-old children of primary education, although the conditions are not yet adequate if they have the desire and awareness, then all of them can direct their children to go to school starting from elementary to junior high (H. Lukman)"

The expression shows that in addition to the factors of facilities, teachers, and facilities, the family confusion factor has a big message for the continuity and success of children's education. It is by [20] that one of the elements of culture is the social environment and family environment. Thus seeing the success factor of education must be holistic, but this condition cannot be separated from the problem of government policy and attention. According to [2] education that there is a strong relationship with the responsibilities of government ruler with knowledge as the fundamental rights of citizens.

Thus, there are many factors to look deeper into the condition of public access to primary education. First is the availability of elementary and junior high education institutions. Secondly as far as the name of the community can reach the educational institution, in this case, starting from the cost at school to all the needs of children in adjusting themselves to various school rules and regulations, including the need for teaching materials. The third is the carrying capacity of education; starting from adequate education personnel, supporting infrastructure, comfort and learning media. Fourth, the presence or absence of non-formal forms of knowledge in package A and package B. Referring to these factors, the condition of community access to education in this village is still lacking:

First, community access to various elementary and junior high school education. From the data, 377 households show that $29 \%$ did not complete primary school and the remainder $50 \%, 18 \%$ of junior high school graduates, 2,3\% of high school graduates, and $3 \%$ of diploma graduates $0,75 \%$. Currently continuing education at PT, namely, through the University Of Muhammadiyah
Kendari (UMK) 2 people and one more person continue to go through Open University. It means that there are only three people currently going to higher education, namely children of H. Lukman (Principal of the elementary school in Saponda), son of the former village head. The results showed that before the existence of SATAP junior high school (Indonesia named), a small number of alumni of the elementary school in Saponda continued to Soropia elementary school, those who were advanced had economic abilities and then proceeded to senior high school. Thus the majority of children graduating from SATAP junior high school (Indonesia named) saponda no longer continue their education at high school. The existence of SATAP junior high school (Indonesia named) to date has dramatically helped the continuation of the school of elementary school alumni in this village, as told by Suriman (29 years) as follows:

"We are very grateful that there is a one-roof SATAP junior high school (Indonesia named) in this village now because since there is a junior high school, the children here continue. If they have graduated from elementary school, then unemployed and no longer go to school. If maintaining outside is not possible because of shipping, transportation. "(Suriman, 28 February 2011).

The statement shows that access and education and facilities are essential for the education continuity of school-age children. When viewed in terms of the time of procuring junior high school education facilities in 2006, it shows that the government does not have the seriousness in guaranteeing the fundamental rights of the community in education-remembering that 9-year primary school is a fundamental right that must be given to all citizens. During this time as a basis, the children did not continue their schooling, even from an average who entered the elementary school around 60-70 people per / year. However, they could finish school only about $40-45$ people. (School data for 2007-2009). This condition shows that around $40-50 \%$ of children in this village have experienced dropouts since elementary school.

Second, the extent to which the community can reach various levels of education. At present, nine years of primary school has been available institutionally in Saponda village, but it has not been balanced with excellent education services. The existence of SATAP junior high school (Indonesia named) ) is beneficial, but both services are of excellent quality learning services. The presence of teachers that only four people cannot serve many subjects in the three classes currently available, then the facility shield only has 3 study rooms, is not supported by a library and teaching aids and learning media.

Third, the carrying capacity of education, that is the supporting power of the implementation of student learning processes in schools today which includes; (1) supporting facilities, namely an insufficient number of classes, no library, and no teaching aids room. This 
condition was discussed with the district education office, but the agency suggested using the BOS (Indonesia named) funds. Meanwhile and BOS (Indonesia named) is limited in nature what else is the construction of physical matters. Currently, BOS funds are more allocated to the purchase of student clothes and stationery, in addition to setting aside for teacher non-permanent teacher incentives. According to the school principal, children in this village if not given books and paper. They do not want to go to school; (2) there are currently only a limited number of teachers, only four people who status as civil servants and four temporary teachers ; (3) Students' access to teaching materials is still limited, and they only rely on textbooks prepared by the school.

The fact is that schools are not possible and are not able to buy textbooks for each student for all subjects. This condition is very much different from schools in other regions. In addition to obtaining easy supporting books, their parents also have an interest in the development of their children's education by purchasing additional books. (4) Government support is still lacking even very much different from the treatment of schools on the mainland. This statement is corroborated by the narrative of La Milu (SATAP Middle School Teachers) viz:

"SATAP Middle School which has been opened since 2006, until now the learning facilities are still limited, such as no library and no teacher's room. To now we are still riding in the elementary school teacher's office, so this has dramatically impacted the ineffectiveness of teaching and learning of the students who are here "(La Milu, 28 February 2003).

From these expressions and narratives show that the junior high school has been running for five years but has not experienced changes and added facilities and teachers. Students and teachers carry out modest learning processes, as do elementary school level education facilities that continue to experience discrimination and local government. This condition is what Gramsci [21] and Wibowo [22] said with soft repressive means that the state performs repressive actions not by military force but by silencing and controlling the dominant reason of the people through a form of false awareness. That what happens and is experienced by the community is merely something natural, natural and development especially in the field of education will run evolutionarily, the community, in this case, the Bajo village of Saponda is quite patient.

This condition is what Gramsci [21] and Wibowo [22] with soft repressive, namely the state undertakes repressive actions not by military force but by the form of silencing and controlling the dominant reason of the people through a form of false awareness. The community experiences that what happens and is merely something natural, natural and development especially in the field of education will proceed evolutionarily, the community, in this case, the Bajo ethnic in Saponda is quite patient. Classes and rooms that not equipped with adequate learning facilities have implications for non-innovative learning systems, and students are less enthusiastic in learning. The following conditions are students in the class that can be seen in Figure 3.

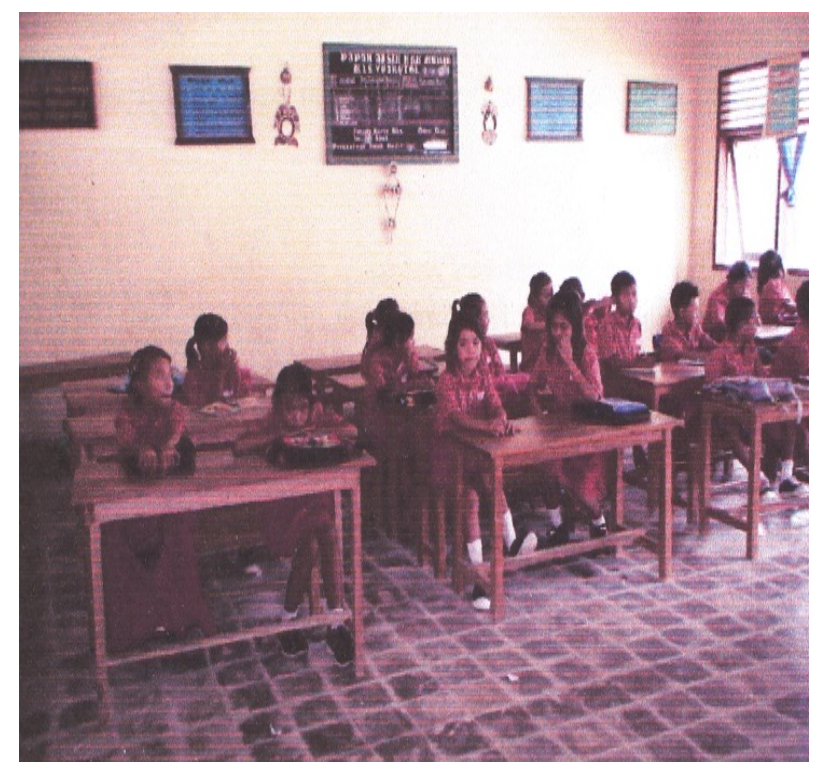

Figure 3. Condition of students in a class (Source: personal documents)

Figure 3 can be observed that the learning situations and conditions of students in the classroom are very monotonous with conventional learning systems and models. Based on observations made by the teacher teaching the lecture method, note, and memorize. This condition is contrary to the meaningful education system mainly when it is associated with critical education theory which in no way builds the essential power and independence of students, as Karim [23] said that critical education in the implementation of the model must prioritize the cooperative method. This teaching style is fun and always oriented to the independence of students in conceptualizing something meaning.

This condition should be an essential concern for both local teachers and the government. The ability of teachers to package and manage classes is unified and the forms of training that should be facilitated by the government, in this case, the education office. The comfort and style of teaching a teacher determine the success and motivation of students in learning. From observations and interviews with teachers, information obtained that in each class, children who do not go to school every day are $20-30 \%$. Usually, they come only during exams, so schools find it challenging to take a strict way because of the conditions and types of people who do not have awareness. The main factor of student laziness is due to lack of community awareness supported by the lack of school facilities and infrastructure. The researcher also clarified to the parents of students who said that very often the students' children at school did not learn and they played more outside the 
classroom because the teacher was still lacking. The condition was since some teachers were continuing their studies to S1. Apart from these conditions, in reality, this school must have the support of various parties, especially the government and the local community.

Fourth, forms of education outside the formal education path. The way of community access marginalization is related to community capacity building outside official channels, namely, package A and package B. There was a package A program and a package B program, but only once. This condition is a form of marginalization of the Saponda Village community that should be implemented with package A and package B programs on an ongoing basis for citizens of primary education age who cannot access formal education at elementary school and SATAP junior high school (Indonesia named).

The description facts about the current picture of the management of education in the Regional Government which has an impact on the imbalance and inequitable access to education received by the community and teachers at elementary school in Saponda. This condition is very contrary to the Regional Policy and National Education Policy. If we look at the direction of the Konawe Regency education policy through the 2010 Education Office Strategic Plan as the technical implementer of education development, we get a vision that is "Creating a Konawe Community that is Smart, Competitive and with Good Morality". Furthermore, it revealed in the form of missions, namely: (1) Providing opportunities for the community to obtain quality education fairly and equitably through formal, non-formal and informal learning, (2) Developing quality education, competitive and relevant to the needs of the community, (3) Striving for the fulfilment and utilization of adequate educational facilities and infrastructure, based on national education standards, (4) Encouraging the improvement of professionalism of educators and education personnel to educate students, and (5) Establishing good cooperation with related agencies, the business world, industry, NGOs, organizations and the Education Council to improve the quality of education.

Related to the marginalization of access to education experienced by the people of Saponda Village, this is the result of the weak attention and commitment of the government in making equal access to education, to bring up its form of interpretation, especially the hegemony that plays behind the fact. Wibowo [22] say that the hegemony process can occur in the form of a struggle for social authority that runs massively on the unconscious. Allowing the Saponda community to give birth to the meaning of a way of duping or leave them in a helpless constellation and situation, difficult to compete with other ethnic communities, and politically they will continue to be spectators and objects of interest in various battles of political affairs.

The government should be able to protect the primary interests of its people, but in The reality, it still leaves the problem of underdeveloped access to education. However, education is a basic need of every citizen that must be guaranteed and given relatively to all people, indiscriminately, and evenly in all corners of the country. Regional autonomy can create optimal community welfare, but in reality, the implementation has not been going well, including in Konawe Regency. Whatever the policies and treatment of the government and surrounding communities towards certain groups can give birth to the interpretation and subjective interpretation of each person avoid the negative meaning of the facts experienced by the Bajo ethnic group, the government must be consistent and fair in implementing educational programs as a translation of the vision and mission of all community groups.

\subsection{Educators}

Educators referred to in this discussion are teachers who functionally have the primary duties and functions as instructors present elementary school in Saponda has four teachers with government employees status (including the Principal). In comparison, non-government employees have nonpermanent teachers. At the same time, for SATAP junior high school (Indonesia named) there are four teachers with details of two government employe teachers and nonpermanent teacher as many as two people. It is clear that this not balanced with the number of students and the number of classes available, this condition has not yet been linked to the preoccupation of most teachers currently continuing to $\mathrm{S} 1$ as many as three people. Then the learning process cannot run effectively. The availability of SATAP teachers in Saponda Village can be seen in Table 1.

Table 1. Availability of elementary and secondary school teachers Village Saponda

\begin{tabular}{|c|c|c|c|}
\hline School & $\begin{array}{c}\text { Government } \\
\text { employees }\end{array}$ & $\begin{array}{c}\text { Non-permanent } \\
\text { teacher }\end{array}$ & Note \\
\hline $\begin{array}{c}\text { Elementary } \\
\text { education }\end{array}$ & 4 person & 4 person & $\begin{array}{c}\text { Most teaching } \\
\text { in junior high } \\
\text { school }\end{array}$ \\
\hline $\begin{array}{c}\text { Junior high } \\
\text { school }\end{array}$ & 2 person & 2 person & $\begin{array}{c}\text { Most of the } \\
\text { Teaching in } \\
\text { Elementary } \\
\text { School }\end{array}$ \\
\hline Total & 6 person & 6 person & \\
\hline
\end{tabular}

Table 1 shows that in general, a non-permanent teacher does not live in this village, so they are not actively teaching. The lack of teachers in elementary school and SATAP junior high school shows the lack of attention and commitment of the local government as the executor in the recruitment and distribution of teachers to schools. The teacher shortage that has occurred since the beginning of this school was created until now there have not been any constructive steps from the Konawe regional government

This fact was also revealed by the teachers in a focus group discussion (FGD), that teacher limitations are a crucial factor in this school. According to them, the 
government should take anticipatory steps by appointing teachers who are still honorariums in this village. Itis is very reasonable given the previous experience that if there are teachers who are placed in this village, then a few years later proposes to move to the mainland. For that reason, the best alternative step is to accommodate the assisting teachers who already exist today. Related to the limited number of teachers, Kadim (head of the Soropia Sub-district Office Branch) also complained about the condition. According to him, since serving as head of the Soropia several times suggested that the teacher recruitment process takes into account the needs of schools

Another factor when a viewed aspect of the marginalization of educators is the absence of efforts to improve teacher competence, both in the form of training and seminars as a form of capacity building. Incessant efforts by the government in carrying out teacher mobility as an effort to increase capacity, as reported by a local newspaper, Kendari Ekspress on October 12, 2010, turned out to be not directly proportional to the treatment of teachers in Saponda. Whereas in this village there are only eight elementary school teachers and six SATAP junior high schools (Indonesia named), generally still need training and empowerment. However, they are currently continuing their undergraduate studies at their initiative, not at the expense of the government.

Based on existing data that, and aspects of teaching staff experience some marginalization, among others;

First, the teacher distribution system that does not pay attention to factors emotionally related between the local population and teachers who are located in this village. Emotional links here are those who come from the Bajo, have assimilation with the Bajo, or they understand the social culture of the Bajo people so that when placed in this village they do not necessarily think of trying to move or going back ashore. Teachers who teach at elementary school / SATAP junior high school are mostly from various areas outside Saponda Village( See Table 2).

Tabel 2. Origin of elementary education / junior high school Teachers in Saponda Village (Source: Year school data)

\begin{tabular}{|c|c|c|c|c|}
\hline \multirow{2}{*}{ School } & \multirow{2}{*}{ Total } & \multicolumn{2}{|c|}{ Origin teacher } & \multirow{2}{*}{ Note } \\
\cline { 3 - 4 } & $\begin{array}{c}\text { Autochthonous } \\
\text { saponda }\end{array}$ & $\begin{array}{c}\text { Outer } \\
\text { Saponda }\end{array}$ & \\
\hline $\begin{array}{c}\text { Elementary } \\
\text { education }\end{array}$ & 8 & 3 & 5 & $\begin{array}{c}\text { Non-permanent } \\
\text { teacher }\end{array}$ \\
\hline $\begin{array}{c}\text { Junior high } \\
\text { school }\end{array}$ & 4 & - & 4 & - \\
\hline Total & 12 & 3 & 9 & \\
\hline
\end{tabular}

Second, the regeneration system and teacher recruitment that does not pay attention to the potential and local resources of the local community. At the moment there are two native people and this village has a D2 qualification while currently as a non-permanent elementary school teacher. The incentive teacher paid as is and regularly, so it has an impact on optimal performance. One of the temporary teachers was named St. Marwah (29 years), hope that in the future teacher recruitment can be covered, considering since the last two years following the selection appointment as a candidate for civil servant but did not graduate, as for the direct interview excerpt as follows:

"I am disappointed because I have participated in a candidate for civil servants twice at Unaaha Konawe, but the results have not passed, he said, we have to prepare the money, so what else can we do, we don't have money to pay. Even though I did not graduate, I will continue to serve here, especially since I am originally from here."

I was observing the expression, Ms ST. Marwah, as explained above that the disappointment of St. This Marwah is reasonable considering that the existence of Saponda Village as a village located in a small archipelago should be supported by teacher resources which should also be culturally derived and the Bajo tribe or residents who indeed live in this place. These complaints and statements are supported by the expression of La Milu, one of the honorary teachers at SATAP junior high school CPNS, in the following explanation:

"I am an alumnus of faculty teacher training and education Halu Oleo University since I have been serving as an honorary teacher for six years, but until now it has not been raised either through candidate for civil servant side selection or through DataBase. Even though he and the Muna, he is willing to settle in this village, because since being placed as honorary staff in this place which is already three years (transfer and junior high school of 1 Soropia) has committed to serve on Saponda Island "(interview) thoroughly.

This case shows that implementing regional policies relating to the recruitment system or potential community regeneration patterns did not go well and were very far away and fulfilling educational needs, mainly formal education in island community groups such as in Saponda Village. The case is contrary to the Konawe district RPJMD (Indonesia name) of 2008, which says that no later than 2011-2012 schools will no longer have a shortage of teachers, at least 60 per cent of teacher shortages can be overcome. But until this research took place, there were no signs of specific services or policies and the government in overcoming the problem of teacher shortages, as happened in SDN Saponda.

Regarding regeneration, the government should individually pay attention to the fundamental problems experienced by isolated communities such as the Bajo on Saponda Island. It is to avoid the flow of teacher transfer to the mainland. If the government is committed to a fair distribution policy and quality education services, then this problem is not something complicated, for example. Other than paying attention to the economic potential that is currently studying S1, can also send or send to PT the children of this island who have graduated from high 
school through a scholarship program, with the regeneration of teaching staff in remote areas. As stated by Makmur (61 years), a community leader in Saponda:

"Since I became the Village Head in 1995, community resources, especially the Bajo tribe, are still low, because here it is probably around 98\% Bajo, their funds are very lacking, they only think that what is essential to be able to read and write is enough, but after I so the Village Head was given training, apparently they were quick to catch the material provided. So actually the Bajo people are smart, and the food is fish, there is just no training or special attention from the government, so I agree that the government is paying attention to the children here who have graduated from high school (the number is not much) so they are given a college school scholarship and go home here to build this village, especially our teacher is very lacking ". (Interview).

The explanation interview shows that community isolated in particular and aspects of the availability of teachers or educators can only be overcome if the government commits by paying attention to special programs in remote areas. The program that can be implemented in this context is the regeneration of the potential of local human resources in remote villages which later after graduating, they are expected to return to being educators in their villages. Thus the occurrence of the transfer of teachers who actually placed them in this village but because they could not survive then took care of moving to the mainland, would not occur.

Third, increasing teacher capacity is very lacking. Efforts to increase the capacity and quality of teachers are a must. It is in line with the national program of improving the quality and education services so that the local government through its technical implementers namely the Education Office must be able to accommodate all the specialized teaching staff of teachers such as on Saponda Island. However, the results study indicate that there has never been a call for training or a form of upgrading for teachers and Saponda Village. The current form of capacity building is through non-regular lectures at the Muhammadiyah University of Kendari and the Open University, which they did on their initiative. The teachers in this place hope that they will be involved in short training conducted by the department and other institutions as a form of efforts to improve their quality and skills.

Lukman (School Principal), often suggested that his teachers be involved in various training, but the attention and the government through the education service were very lacking. Regionally, its position as a senior high school island and community context are still shallow in human resources, so remote areas must prioritize, but in reality, it is not so. Thus experienced by the teachers in this village is a fact of exclusion from the service aspect of empowering teacher competitiveness. This condition is relevant to the terminology described by Gramsci [21], and
Spivak [24] said that this form of isolated would occur not because of isolated territorial conditions, but because of the position of the existence of certain groups (Bajo ethnic) placed as subordination (second class society). So that culture will give birth to attitudes and distrust of the government. According to Makmur (February 28, 2011) 8 years of fighting for junior high school in this village to the point that he felt that the form of injustice in the government's treatment of them was due to the existence of the Bajo ethnic which always used as a second class (subordinate) and other community groups.

Fourth, the lack of special incentives for teachers who work in Saponda Village. Searching for several honorary teachers both in elementary education and junior high school has inadequate welfare constraints; this is because the forms of attention and incentives provided are very minimal. According to Marwah ( Middle School Teacher) said as follows:

"If we hope that incentives are not enough, we will carry out this responsibility solely because we feel that this is our hometown. If it is not we who pay attention to our village, who else? Teachers here, including me, hope that this dedication can lead to the appointment of government employees in this village" (interview).

The same thing is related to the same problem, also said by La Milu (Non-permanent teacher in junior high school), which is as follows:

Even though I am not yet a civil servant, I have already been certified as a professional teacher, so starting in 2010, I have received a certification allowance. In my opinion, the certification allowance, which is the same value as the salary of a civil servant, is very supportive of my life and performance in carrying out his duties as a teacher at Saponda Middle School. But the desire to be bound in the status of civil servants still I hope, we can also do the teaching assignments calmly "(interview).

Still, in the same case, Ms Murni alumnus Halu Oleo University in 2009 Psychology Study Program, who is currently honorary at the Saponda Middle School, said:

"Carrying out assignments as a Counseling Teacher based on devotion with modest incentives which he said was taken from BOS funds would certainly not be enough, because if it was related to spending my living needs here. It was not enough, So this sacrifice I hope that the government will pay attention by making us permanent teachers in this school this is also for the success of the children here because if it is still an honorarium status like this, of course, teaching is also not optimal (interview).

From the expressions of these teachers who are honorary teachers, they illustrate that welfare cannot underestimate, this is in line with various education experts, including Tilaar [2] in the contingent education paradigm, the factor of teacher welfare is essential. An increase in teacher welfare should accompany the high demand for improving 
the quality of education outcomes. This basis also underlies the current government policy continues to increase the cost of national education even though its implementation has not been evenly distributed, especially in certain areas such as Saponda Village. Teachers are still very limited in their welfare because they only expect their salary. Expecting full performance and service and teachers who are still honorary is very unlikely. Thus the forms of educational services provided by them in the form of 9-year formal education are not going well. It is a form of educational isolated experienced by the people in this village. This condition requires more serious handling both from the regional and central government.

\subsection{Research Finding}

Based on the results of the study, several things can be stated that are stated as research findings, as described: There is still unfair treatment by the government of the Bajo ethnic community, such as education services, especially primary education, both aspects of education facilities, the availability of teachers and the educational process that not based on the environmental conditions of the surrounding community. This condition is contrary to Law No. 20 of 2003 concerning primary education. The government has not yet succeeded in holding the mandate to isolated community groups such as those on senior high school islands.

\section{Conclusions}

Referring to the description of the findings that have been presented, it can be concluded: (1) The form of exclusion is inadequate access to education, limited (school) education facilities, inadequate learning facilities, lack of teachers so that it not yet balanced between the number of teachers and the number of classes and subjects that must be provided. As a result, the learning process does not run effectively every day. Besides that, the learning process given so far is still conventional, less fun because it uses the lecture method and does not use learning media that is enthusiastic, less interested, and lazy to go to school and results in dropping out of school; (2) The marginalized of primary education have a low level of community education which has implications for low human resources and technology adoption skills, high unemployment conditions, and poverty conditions.

\section{Acknowledgements}

The researches would like thanks to the Head of the Southeast Sulawesi Provincial Education Office, Head of Konawe Education Office, Head of Soropia Sub-Regency, School Principals, Teachers, Heads of Saponda Village, Community Leaders, Student Parents, and all students in
Saponda Village for all information provided so that research can be completed. Data obtained through informants can be valid. We are grateful to thank the Halu Oleo University for supporting and mandating this study so that useful data can be obtained and can be used as a reference for national and world researchers to conduct more studies on the Bajo ethnic, especially in Southeast Sulawesi, Indonesia as well as gratitude to the Doctoral Program at the University of Udayana Indonesia who have fully supported this dissertation so that it can be resolved.

\section{REFERENCES}

[1] A. Green, A. W. Little, S. G. Kamat, M. Oketch, and Edward Vickers, Education and development in a global era: Strategies for'successful globalisation, London: DFID, 2007.

[2] H. A. R. Tilaar, Paradigma baru pendidikan nasional, Jakarta: PT. Rineka Cipta, 2000.

[3] K. Nomura, "A perspective on education for sustainable development: Historical development of environmental education in Indonesia," Int. J. Educ. Dev., vol. 29, no. 6, pp. 621-627, 2009, doi: 10.1016/j.ijedudev. 2008.12.002.

[4] D. Craissati, U. D. Banerjee, L. King, G. Lansdown, and Alan Smith, "A Human Rights Based Approach to Education For All,” Ulster University, 2007. [Online]. Available:https://pure.ulster.ac.uk/en/publications/a-human -rights-based-approach-to-education-for-all-3. [Accessed: 19-Dec-2019].

[5] I. Haris, F. A. Naway, W. T. Pulukadang, H. Takeshita, and I. V. Ancho, "School supervision practices in the indonesian education system; perspectives and challenges," J. Soc. Stud. Educ. Res., vol. 9, no. 2, pp. 366-387, 2018, doi: $10.17499 /$ jsser.17724.

[6] S. W. Sinding, "Population, poverty and economic development," Philos. Trans. R. Soc. B Biol. Sci., vol. 364, no. 1532, pp. 3023-3030, 2009, doi: 10.1098/rstb.2009.0145.

[7] “Census-2007 Report,” Ethipia, 2007.

[8] L. O. A. Basri, I. W. Mudana, and A. Rahman, "The Negative Stigma Against the Bajo Tribe and its Impact on Local Culture: Study of the Bajo Tribe in Bungin Village of South Konawe," Asian Cult. Hist., vol. 9, no. 2, p. 90, 2017, doi: 10.5539/ach.v9n2p90.

[9] U. UNESCO, GEM report: education for people and planet, Second Edi. Frances: United Nations Educational, Scientific and cultural organization, 2016.

[10] S. Syam, A. Yudono, R. Wikantari, and A. Harisah, "Architecture spatial arrangement of Bajo tribes settlement in Kabalutan Island of Central Sulawesi," IOP Conf. Ser. Earth Environ. Sci., vol. 202, no. 1, pp. 1-8, 2018, doi: 10.1088/1755-1315/202/1/012062.

[11] I. M. K. A. Darman, A. J. Ladianto, and W. O. N. Hamundu, "Wujud kearifan local masyarakat suku bajo terhadap 
orientasi bangunan pemukiman dalam merespons iklim tropis [The manifestation of local wisdom of the Bajo tribe towards the orientation of residential buildings in responding to the tropical climate]," in Seminar Nasional Teknologi Terapan Berbasis Kearifan Lokal, 2018, pp. 110.

[12] A. S. Sjamsu and I. M. K. A. Dahrma, "Studi kelayakan potens ipengembangan desa wisata di kawasan pulau saponda dalam kabupaten konawe [The feasibility study potential development of rural tourism in the island region Saponda in Konawe].,” in Seminar Nasional Teknologi Terapan Berbasis Kearifan Lokal, 2018, pp. 1-50.

[13] Y. K. Artanto, "Bapongka, system budaya suku bajo dalam menjaga kelestarian sumber daya pesisir,” Sabda J. Kaji. Kebud., vol. 12, no. 1, pp. 52-69, 2017.

[14] J. Stigler and James Hiebert, The teaching gap: Best ideas from the world's teachers for improving education in the classroom, Reissue Ed. New York: Free Press, 2009.

[15] F. Balsamo, Education Access [microform]: National Inquiry into Rural and Remote Education, First Edit. Sydney: Human Rights and Equal Opportunity Commission, 2000.

[16] Y. Xu, W. Song, and C. Liu, “Social-spatial accessibility to urban educational resources under the school district system: A case study of public primary schools in Nanjing, China," Sustain., vol. 10, no. 7, pp. 1-16, 2018, doi: 10.3390/su10072305.

[17] B. Pont, D. Nusche, and Hunter Moorman, Improving School Leadership, Fist Editi. OECD, 2008.

[18] S. L. Muhammad, R. Syamsiar, W. Andi, R. M. Rum, and Hardiyanti Iva, "Identification of hazard and risk occupational health in lumu-lumu island fisheries," Indian J. Public Heal. Res. Dev., vol. 10, no. 1, pp. 1193-1198, 2019.

[19] Sugiyono, Educational Research Methods Quantitative, Qualitative Approach and R\&D, Bandung: Alfabeta, 2014.

[20] Hasbullah, Dasar-dasar ilmu pendidikan [The basics of education], Jawa Tengah: Rajawali Pers, 2009.

[21] G. A, Further selections from the prison notebooks, UK: University of Minnesota Press, 1971.

[22] I. Wibowo, Negara dan masyarakat: berkaca dari pengalaman Republik Rakyat Cina, First Edit. Jakarta: PT Gramedia Pustaka Utama bekerja sama dengan Pusat Studi Cina, 2000.

[23] K. M and Meitasandrashanti, Pendidikan kritis transformative [Transformative critical education], Yogyakarta: Ar-Ruzz Media, 2009.

[24] G. C. Spivack, Membaca pemikiran Jacques derrida sebuah pengantar [Thought reading jacques derrida an introduction]. Yogyakarta: PenerbitAr-Ruzz, 2003. 